haustive, ... dans ce livre. Environ 400 sources historiques et contemporaines provenant des 20 Pays arabes ont été dépouillées pour cet ouvrage qui couvre tous les aspects des droits de l'homme", so der Klappentext. Sowohl die Breite des Zuschnitts als auch die Materialfülle sind tatsächlich beeindruckend. Nur läuft ein solches Werk immer Gefahr, zu zu vielem zu wenig zu sagen oder den Leser mit zu vielen, unverbunden erscheinenden Daten zu verwirren. Das gilt besonders bei einer Arbeit, die, wie die hier besprochene, mehr Wert auf Fakten legt als auf einen theoretischen Unterbau. Aldeeb Abu-Sahlieh hat diese Gefahren jedoch weitgehend gemeistert und eine sehr wertvolle Pionierleistung vorgelegt, die es nun mit weiteren Monographien zu ergänzen gilt. Es bleibt zu hoffen, daß die wohl wichtigsten Anliegen des Autors Realität werden: Entpolemisierung der Diskussion und Verbesserung der Menschenrechtssituation in den arabischen Staaten. Seine Arbeit kann dabei Hilf estellung leisten.

Johannes Christian Wichard

\title{
Juhani Koponen
}

\section{Development for Exploitation: German Colonial Policies in Mainland Tanzania 1884-1914}

Finnish Historical Society - Studia Historica 49

Lit-Verlag - Studien zur Afrikanischen Geschichte 10, Helsinki / Hamburg, 1995, 741 pp., DM 88,80

In 1994 in a raging debate on the union between Mainland Tanzania (Tanganyika) and Zanzibar forming the United Republic of Tanzania and its future, one of the founders of the Union, the former President of Tanzania, Julius Kambarage Nyerere, wrote a book in Kiswahili now translated in English entitled: "Our Leadership and the Destiny of Tanza nia" $^{1}$ in which he passionately defended the union. In it he at length argued that Mainland Tanzania was a creation of Imperial Germany while the Union of Tanzania was a creation of Tanzanians themselves after extricating their countries from colonialism under the British. One would have dismissed Nyerere's reference to Germany as a stretched and may be argument to win a point. But in reading the book on German colonial period in Mainland Tanzania by the Finnish social scientist and historian Juhani Koponen one appreciates Nyerere's assertion. Koponen states: "So far, the German Schutzgebiet (protectorate) in East Africa had been a mirage. It existed only on European maps, in the minds of German colonial enthusiasts and agitators in the correspondence of European foreign ministries. It did not exist on the ground in Africa. The area which the Germans claimed covered almost a million square kilometres, roughly twice that of the Reich itself. Reaching from the 
verdant humidity of the coast of the Indian Ocean over the parched plains of the East African plateau to the great lakes at the heart of Africa, it encompassed a wide variety of microenvironments. It was inhabited by dozens of indigenous peoples who represented most major linguistic and cultural groups and modes of production in Africa. ... The colony did not exist; it had to be made" (p. 87).

Koponen has already written another seminal book in 1988 about Tanzania under the title "People and Production in Late Pre-colonial Tanzania". This new book by Koponen, which may be considered to be a follow-up to that on pre-colonial Tanzania, is the first systematic and comprehensive analysis of German colonial period in Tanzania. This fact is not only proved by the voluminous size of the book but by the themes covered, very detailed notes and a rich bibliography of both primary and secondary sources used in it and the methodology applied in evaluating them, showing that the study of the colonial past and its impact on the present is very complex and contradictory. That is one of the factors that makes this book to be a significant scholarly contribution to the study of Tanzania taking into account that many have written excellent books on the German colonial period in East Africa.

As the title of the book indicates, the main issue that Koponen sets out to discern and present to his readers is that of relationship between colonialism, exploitation and development. Here the author comes out with relatively controversial and though provoking arguments. Commenting on the statement by some writers that the history of modern economic development in Tanganyika was extremely short beginning in 1884 the year it was founded as a German colony, Koponen now submits that "at present, I see inaccuracy in the suggestion of the economic development having begun in 1884, but by and large I now agree that not only 'modern economic development' but also much else we nowadays call 'development' began in Tanzania during German colonialism" (p. 9). Nevertheless, Koponen does not at all make an apologetic study on colonialism, as he himself puts it: "Yet I have found no reason to relinquish my early belief that colonialism was essentially an exploitative system. This study is an attempt to explain such a position" (ibid.). He argues that one of the purposes of his book is to present a critique of the accepted everyday use of the terms colonialism, development and exploitation. Certainly, that opens up a debate especially among historians and social scientists but also other interested scholars.

Aspects covered in the book are wide ranging and may be of interest to different academic disciplines. It covers the creation of the colonial state and its administrative structure and the making of economic agents in German East Africa which included the co-option of the Indian trader class who today dominate and control the industrial and commercial sector in Tanzania. There is a whole Chapter on "The Creation of Labour" through both forced labour and contract labour legislation during this period. The author discusses the introduction of taxation also as one to the methods of forcing African to work for the colonial economy in order to raise money to pay tax, and the importation of Chinese, Javanese and Malayans coolis from East Asia as labourers in German East Africa. Labour legislation during this period forms the basis of the section of the book with a sub-heading "Disciplining: Law and Lash" where criminal sanctions such as flogging were applied to 
discipline the African labourer. Cash crops such as cotton, sisal, rubber and coffee were introduced and planted either in plantations or some like cotton and coffee by smallholders. These crops with the exception of rubber have remained the major cash crops of the present Tanzania. The use of force by the Germans in ensuring the cultivation of these cash crops is one of the reasons which the Maji Maji uprising of 1905 to 1907 which as Koponen says was "the most violent and widespread mass resistance to German colonial rule in East Africa and indeed the greatest uprising in the whole early colonial Eastern and Central Africa" (p. 229).

One of the interesting chapters is that on "Development of Technology and Resources" where the author deals with such items as transfer of technology, population and health in which names such as of Professor Robert Koch are mentioned in relations to their researches in Mainland Tanzania, epidemic control veterinary services, and infant and child mortality and birth rate. There is a whole section on control and conservation of natural resources detailing forest protection and wildlife preservation. The section on African schooling in public schools run by the German colonial administration and those owned by the different christian mission societies gives very interesting information on the development of the school system and structure during this period and the whole question of colonial schooling and civilisation. All these aspects as shown in the book had an impact in the present Mainland Tanzania.

The book ends with two chapters in which the author recaptures again his main arguments, one on "Colonial Development: Beyond Intention" and the other is the conclusion with a heading "Colonial Development Revisited" with a section entitled "Development and Underdevelopment: Means and Ends" where he dialectically sums up his arguments by saying that "... development and underdevelopment cannot be seen as separate, let alone qualitatively different historical phenomena. In one sense, underdevelopment is merely another, more forceful name for colonial development. In another sense, development was an essential part of the mechanisms of underdevelopment" (p. 671).

This book by Koponen is not only a systematic and detailed study but an invaluable source of information and fills a significant gap in the study of the history and development of Mainland Tanzania and indeed a must read to those interested on Tanzania. Hopefully, as wished by Koponen himself, his book may inspire both German and Mainland Tanzanian historians to undertake a similar project, especially now that, with the unification of Germany, the documents in the archives in the former East Germany are fully accessible to all scholars. 